\title{
Who is He Now: David Bowie and the Authentic Self
}

\author{
Bethany Usher and Stephanie Fremaux
}

TWO important milestones - the $40^{\text {th }}$ anniversary of the release of Ziggy Stardust and his $65^{\text {th }}$ birthday - ensured renewed media and public interest in David Bowie in the two years leading to the unexpected release of The Next Day in 2013. However, this coverage largely focused on the red haired spandex clad (mass) mediatised icon of the 1970s (McCleod 2013, Cann 2010, Doggett 2011, Jones 2012, Trynka 2012, Goddard 2013) and journalists overwhelmingly tried to place The Next Day in a context relating to this material (Sheffield 2013, Cavanagh 2013, Harrison 2013). As Tony Parsons (2013, Online), former NME 'gunslinger' and now Mirror stalwart declared, it was all: 'wild speculation....because Bowie, for once in his life, isn't talking'; strange as Bowie was 'always the easiest artist in the World to talk to: open, engaging, hiding nothing'. Since the creation of his earliest complete persona, Ziggy Stardust, he utilised music and news press not only promote his material but to create and maintain the illusion the incarnation he had created was his authentic self. While a common process amongst stars and celebrities, this was something Bowie would later try to distance himself from in the 1990s, as this piece illustrates. Following Weber's ( 1947 in Eldridge 1971, p. 229) concept of 'charismatic authority' and its reliance on 'followers or disciples' accepting the individual as a valid symbol for an age, and Dyer's (1986, p. 3) model of 'extensive, multimedia and inter-textual' production for celebrity, the creation of Ziggy was multi-faceted and consistent. The marketing campaign devised by Bowie and his 'cultural impresario' Tony Defries centred on his 'capacity to express ambiguity and change' (Rojek 2001, p. 134). Ziggy's 'value of visibility' (Holmes and Redmond 2006, p. 5) was drawn from his potency as a symbol of the sexual and social instability of the time and Bowie has acknowledged the media and publicity machines' role in its success ( Jones 1977). The level of validation offered by both the media and fans is perhaps best evidenced by their inability to differentiate the retirement of the character from the end of Bowie's musical career (see Hollingworth 1973). Now, by staying silent, Bowie gives publications and fans space to imagine the version of him they want as the current one.

Twenty years ago $Q$ digitally imposed the Aladdin Sane stripe over Bowie's face for the May 1993 cover which Bowie himself declared 'cheeky'. Their utilisation of the Aladdin Sane image on their front cover again in April 2013 was therefore both nostalgic for the Bowie fan and for the $Q$ reader. Even with the release of new material, $Q$ are clearly still more engaged by previous personae, releasing a 30 page special in April 2013 that covers each decade of Bowie's career with one notable 
exception: the 1990s. While each period is described as being of musical merit, Tin Machine (Bowie's band from 1988 - 1992), Outside (1995), and Earthling (1997) are consigned to the Bargain Bin of 'Bowie's Disasters', ( $Q$ April 2013, p. 70) referred to as 'a decade of painful reconstruction' ( $Q$ April 2013, p. 92) and then ignored in their glossy double page spreads.

It is ironic that $Q$ gave so little space to the period between 1989 and 1999 as it was then they had greatest access to the star. $Q$, launched in 1986, had a total of seven interviews during this time which can be categorised into two distinct categories: the retrospective, which considers Bowie in terms of a linear narrative of creative progression, and discussions of new material and current creative identity. Within these articles, while the interviewers often aim to place Bowie's new material in some form of linear context which fit a 'rise and fall' trajectory of commercial or critical success, Bowie often appears unwilling to do so. He is keen to establish that while he understands the dominance and endurance of past versions of self as part of their success as mediated creations, they were just passing moments in his career. New material is something distinct, particularly from the Ziggy identity of the 1970s and the commercial success of the 1980s. As one interviewer, Adrian Deevoy describes:

You sense a flurry of retrospective activity might be attempts to reconcile the fractured, even splintered, elements of Bowie's complex, some would say schizophrenic character; that he is consigning the battered pieces of his past to life's overhead locker... (Q May 1993, p. 74).

The fact $Q$ are so dismissive of this period is symptomatic of the mainstream media's unwillingness even twenty years after Deevoy's description - to allow Bowie to escape the characters he created. Bowie's previous personae were fabricated and mediated but accepted as authentic by audiences looking for symbols of their age (Schickel 1985). In the 1990s, he consistently demanded to be accepted for a version closer to reality, keen to be seen as an authentic member of the current age in order for his new material to be accepted as culturally resonant (Marshall 1997, Meyer 2009). These demands were ultimately rejected. In order to place The Next Day into the context they want, $Q$ ignores Bowie's own repeated insistence the '90s were a period of deep artistic and personal significance. When discussing this material he was excited and dynamic, offering glimpses into inspirations, influences and processes with far greater links to The Next Day than earlier periods. This era, kick started by Tin Machine, acted as a cathartic cleansing of the performance of characters and commercial pressures. Tin Machine, for Bowie was an exercise in 'getting back on course...for my musical sanity... I had to get passionate again. I couldn't keep going the way I was going' ( $Q$ June 
1989, p. 65), while the mid-1990s albums Outside and Earthling he sees as part of his 'artistic survival' ( $Q$, February 1997, p. 59) categorised by his desire not 'to throw my chance to experiment away' (Ibid, p. 56) and to produce something relevant regardless of its commercial impact. His final interview of this period demonstrated an attempt 'to capture the idea of songs for my generation,' describing how he had to 'sink into a situation psychologically that was less than happy in life' ( $Q$ October 1999, p. 90). In order for the multimedia image of Ziggy to work he existed as the character and caused psychological damage as he struggled to 'divide' the character from himself. (Rojek 2001, 2012). Now he is able to divide his artistic process from the reality of his day-to-day life. The ignored $Q$ interviews are therefore significant original source material which offer insight into this period of artistic discovery and give context to the production of The Next Day.

In his last interview with $Q$ in the 1990s, Bowie declared:

'I am only the person the greatest number of people believe I am. So little of it has anything to do with me...' (Q October 1999, p. 90).

It could be argued that Bowie's current silence is symptomatic of his understanding that whatever he says The Next Day will be seen in relation to and judged against his 1970s outputs. If so, he was right. Andrew Harrison's (April 2013, p. 93) review for $Q$ declares: 'There's full on '70s glam swagger on 'Valentine's Day' and the tragic tropes of 'Drive-in Saturday' on penultimate song 'You Feel So Lonely You Could Die," stating the album is 'the best since (and including) Let's Dance.' During the 1990s, Bowie attempted to use interviews with $Q$ to move on from this period, but failed. Despite his own repeated insistence of the importance of the period in finding a sense of authentic self - free from the constraints of the characters which dominated his 1970s output and from the commercial pressures of the 1980s - it is still not seen as valuable by the very publication he was speaking to. Whatever he said then or says now, the narrative of Bowie's career is long established, both by long term fans who want to relive the Bowie of their past and by the mainstream media who are happy to indulge them. Anything that doesn't fit the mould is at best dismissed and at worse consigned to a 'Greatest Gaffs' bargain bin.

Just out of view, like in the video for 'Where Are We Now?' stands Bowie himself, watching as they all project into the space left by his silence. But, arguably he has still had his say. The Next Day's title and cover could be seen as comment to the forever nostalgic fans and critics. If they want another 'Heroes', that is what he will give them and he has even recycled the cover. Just as mainstream media suffer from a time lapse when providing images of Bowie - using pictures from 40 years before to celebrate his $65^{\text {th }}$ birthday and ignoring periods which do not fit their narrative of his 
career - the large white square and the scratched out 'Heroes' scribbles out the years between that album and The Next Day. It is clear that he is a confident artist who has gained self-autonomy from the industry, press, and fans and their expectations of him. The fact those expectations still dominate media coverage no longer matters because 'so little of it has anything to do with [him]' anyway ( $Q$ October 1999, p. 90). Therefore, there is nothing to be gained from speaking at all.

Word count: 1558

References:

Aston, M., 1997. "Dizbusting David Bowie hopes you like his newish direction." Q Magazine. August. Baudrillard, J., 1994. Simulacra and Simulation. Ann Arbor, MI: University of Michigan Press.

Bowie, D., 1995a. "The Diary of Nathan Adler or the Art-ritual murder of Baby Grace. An occasionally on-going short story." Q Magazine. January.

Bowie, D., 1995b. "Internet conversation between David Bowie and Brian Eno." Q Magazine. January.

Cann, K., 2010. Any Day Now: David Bowie The London Years (1947 - 1974). London: Adelita Ltd.

Cavanagh, D., 1997. “Bowie at 50!” Q Magazine. February.

Cavanagh, D., 2013. “Why has he come back?” David Bowie feature. Uncut. April. $32-41$.

Deevoy, A., 1989. "Ready to rock? David Bowie 'back on course' with Tin Machine." Q Magazine. June.

Deevoy, A., 1993. “'God, I remember this': David Bowie, this is your life." Q Magazine. May.

Doggett, P., 2011. The Man Who Sold the World: David Bowie and the 1970s. London: Vintage.

Du Noyer, P., 1990. "Put your hands together for...Ziggy Stardust! The Thin White Duke! The Laughing Gnome! (?) David Bowie in the $Q$ interview." Q Magazine. April.

Dyer, R., 1993.The Matter of Images. London: Routledge.

Dyer, R., 1986. Heavenly Bodies. Oxon: Routledge.

Eldridge, J.E.T., ed., 1971. Max Weber: The Interpretations of Social Reality. London: Nelson.

Forde, E., 2013. “Bowie Disasters: The Dame Busters." Q Magazine. April. 70.

Goddard, S., 2013. Ziggyology. London: Ebury Press.

Harrison, A., 2013. "Speed of Life: The Next Day album review." Q Magazine. April. 92 - 93. 
Hollingworth, R., 1973. Melody Maker. 14 July. Reprinted in Uncut. Ultimate Music Guide: David Bowie. (2011). Issue 7. $44-45$.

Holmes, S. and Redmond, S., eds., 2006. Framing Celebrity. Oxon: Routledge.

Jones, A., 1977. Melody Maker. 29 October. Reprinted in Uncut. Ultimate Music Guide: David Bowie. (2011). Issue 7. $71-74$.

Jones, D., 2012. When Ziggy Played Guitar. London: Preface Publishing.

McLeod, K., 2003. "Space Oddities: Aliens, Futurism and Meaning in Popular Music." Popular Music. 22:3. $337-355$.

Malins, S., 1998. “Looking good Davie! Feeling good Ig?” Q Magazine. April.

Marshall, P. D., 1997. Celebrity and Power. Minneapolis, MN: University of Minnesota Press.

Meyers, E., 2009. Can You Handle My Truth? Authenticity and the Celebrity Star Image. The Journal of Popular Culture. 42:5. 890 - 918.

Parsons, T., 2013. "Are health fears behind the welcome return of David Bowie?" Mirror [online]. 10 Jan. <http://www.mirror.co.uk/lifestyle/going-out/music/tony-parsons-on-david-bowie-health1527186>. [Accessed 10 June 2013].

Pegg, N., 2011. The Complete David Bowie. London: Titan Books.

Quantick, D., 1999. “Now where did I put those tunes?” Q Magazine. October.

Redmond, S. and Holmes, S., eds., 2007. Stardom and Celebrity: A Reader. London: Sage.

Rojek, C ., 2001. Celebrity. London: Reaktion.

Rojek, C ., 2012. Fame Attack. London: Bloomsbury Academic.

Schickel, R., 1985. Intimate Strangers: The Culture of Celebrity. New York: Doubleday.

Shaar Murray, C., 1991. "Are Tin Machine crap? Discuss.” Q Magazine. October.

Sheffield, R., 2013. "The Next Day album review." Rolling Stone [online] 28 Feb.

$<$ http://www.rollingstone.com/music/albumreviews/the-next-day-20130228>. [Accessed 10 June 2013].

Trynka, P., 2011. Starman: David Bowie - The Definitive Biography. London: Sphere. 